\title{
Application of CORE Learning to Improve Mathematical Connection Capabilities and Self-Efficacy
}

\author{
Eka Yanuar Ramadhani*, Anggun Badu Kusuma \\ Prodi Pendidikan Matematika, Fakultas Keguruan dan Ilmu Pendidikan, \\ Universitas Muhammadiyah Purwokerto \\ E-mail : yanuarekaramadhan@ gmail.com
}

\begin{abstract}
The study aimed to improve the skills of students mathematical connections and self-efficacy for grade VII D of SMP N 3 Sidareja in the 2018/2019 academic year through CORE (Connecting, Organizing, Reflecting, and Extending) learning on the topic of triangles and rectangles. The study was conducted in three cycles and each cycle consisted of planning, action, observation, evaluation, and reflection stages. The instrument used was a description test to measure the skills of students' mathematical connections given at the end of each cycle, while the instrument used to measure self-efficacy was self-efficacy questionnaire. Based on the findings, each cycle obtained an improvement. The first cycle obtained mathematical connection skills by an average of $64.74,77.24$ in the second cycle, and 81.41 in the third cycle. The average results of students self-efficacy in grade VII D in the first the cycle was $69.67,76.05$ in the second cycle, and 79.85 in the third cycle. Based on the data above, it can be drawn that there was an improvement of students' mathematical connection skills and self-efficacy from cycle I to cycle II and from cycle II to cycle III through CORE learning (Connecting, Organizing, Reflecting, and Extending).
\end{abstract}

Keywords: Mathematical connections; Self Efficacy; CORE (Connecting, Organizing, Reflecting, and Extending) learning

\section{INTRODUCTION}

Mathematical connection ability is one of the cognitive abilities that students must possess. According to NCTM (2000) states that one of the basic abilities that must be possessed by students is the ability of mathematical connections. According to Ruspiani (Sumarmo, 2007) explained that mathematical connections are the ability to link between mathematical concepts both linking between mathematical concepts themselves and mathematics with other fields. According to Lappan (2002) states that a mathematical connection is a learning activity where students can determine solutions by understanding or analyzing a problem related to daily life. According to Sugiman (2008) that by having a mathematical connection, students will be able to link between mathematical topics, mathematics with other sciences, and mathematics with everyday life. This means that if students have good mathematical connections, students will be able to link sub-materials in the subject matter of mathematics, a link between concepts in the field of mathematics, and associate mathematics with everyday life. Based on the explanation above, it can be concluded that the mathematical connection is the ability of students to recognize and understand the relationship between sub-material in the subject matter of mathematics, the relationship between concepts in the field of mathematics, as well as applying mathematics to everyday life. The mathematical connection indicators are as follows: (1) Recognize and connect the relationships between sub-materials in one mathematical 
subject matter; (2) Understanding the relationships between concepts in the field of mathematics; (3) Recognize and apply mathematics in everyday life

The purpose of learning not only makes students able to understand the contents of the material, but there are other goals, namely students can develop mathematical connection skills and the existence of certain behavioral changes after learning mathematics (Subandar, 2007). Someone said to be successful in learning if there are changes in cognitive abilities and affective changes, especially in behavior. One of the affective aspects is self-efficacy. According to Bandura (1997), self-efficacy is a belief that is a determining factor in human thought, motivation, and human action. According to Santrock (2014) students who have low self-efficacy will avoid difficult tasks, while students who have high self-efficacy will feel challenged to complete these tasks. According to Bandura (1997), self-efficacy is a belief that is a determining factor in human thought, motivation, and human action. Self-efficacy is a key factor in someone's actions, what people think, believe, and feel will influence how a person acts. So self-efficacy is a belief in its ability to organize and carry out actions by predetermined goals. The indicators of self-efficacy are as follows: (1) Able to complete tasks that are easy to difficult; (2) Able to deal with mathematical tasks beyond ability; (3) Able to persevere and be tenacious in doing math tasks; (4) Influence of personal experience; (5) Readiness to deal with situations.

Based on the results of an interview with a mathematics teacher at SMP N 3 Sidareja, it was found that the students' ability in connecting between the previous concepts and the concepts to be learned was still considered difficult by students. what is known in the problem? Students are also troubled by story problems or problems related to daily life, the proof is that when teachers give to story questions there are still many students who have not been able to change these questions into mathematical models. Aside from the results of the interview, this was also strengthened by the observation data in the form of the pretest giving showing that the mathematical connection ability in SMP N 3 Sidareja class VII D was still very low compared to other classes. The average grade of pretest grade VII D is 43.91 .

Another problem faced by students is that the majority of students do not pay attention when the teacher explains the material, are lazy to practice, and do not have high motivation to learn. This causes 1) Students do not have confidence in what they are doing, this is proven when the teacher asks about math problems, students are reluctant to answer for fear of being wrong, 2) Easy to despair in working on difficult questions, for example when the teacher gives questions that are difficult and students can not answer, just leave it or even see the results of their friends' answers, 3) Not ready to face the situation, for example when the teacher suddenly gives an evaluation test or daily tests without notifying them first. Based on this it can be seen that students' self-efficacy is also still low. One effort to improve the ability of mathematical connections and self-efficacy is through learning CORE (Connecting, Organization, Reflecting, Extending). CORE learning is an abbreviation of four words namely Connecting (Connecting old information with new information or between concepts), Organizing (organizing the information obtained), Reflecting (rethinking information already obtained), Extending (extending and deepening knowledge). According to Lestari (2015), CORE is learning that emphasizes the students' experience by constructing their problems by connecting, organizing, and reflecting on learning that has been experienced and extending the learning experience. This CORE learning offers a learning process that gives space for students to think, practice their memory of a concept, build their knowledge. This will provide a different 
experience so that it is expected to improve students' mathematical connection skills and self-efficacy.

\section{RESEARCH METHOD}

This research was conducted in class VII D of SMP Negeri 3 Sidareja. The time of the research is 27 April 2019 until 18 May 2019 in the even semester of the 2018/2019 school year. The number of students in class VII D is 26 students. This study consisted of three cycles, each of which consisted of two meetings. At the first meeting, 2 x 40 minutes is used for the implementation of the learning process. The second meeting is $3 \times 40$ minutes, where $2 \times 40$ minutes is used for the implementation of learning and $1 \times 40$ minutes is used for evaluation tests to find out the mathematical connection ability and student's self-efficacy. Data collection techniques in this study were using teacher activity observation sheets, student activity observation sheets, evaluation tests of mathematical connection ability, and self-efficacy questionnaires. Data analysis techniques used in this study were analyzing the results of teacher activity observation, student activity observation, ability mathematical connection, and self-efficacy.

\section{RESULT AND DISCUSSION}

From the results of research in the first cycle, second cycle, and the third cycle can be described as follows:

1. Teacher activities

Teacher activities during learning show that teachers always try to improve learning from cycle I, cycle II, and cycle III. The percentage of average scores for teacher activities can be seen in the table below:

Table 1.1 Recapitulation of Teacher Activity Results

\begin{tabular}{clllll}
\hline Number & Cycle & Meeting & \multicolumn{2}{c}{ Implementation } & \multirow{2}{*}{ Average } \\
\cline { 3 - 4 } & & & Yes & No & \\
\hline \multirow{2}{*}{1} & Cycle I & P1 & 14 & 3 & $85,29 \%$ \\
\cline { 3 - 4 } & & P2 & 15 & 2 & \\
\hline \multirow{2}{*}{2} & Cycle II & P1 & 16 & 1 & $94,12 \%$ \\
\cline { 3 - 4 } & & P2 & 16 & 1 & \\
\hline \multirow{2}{*}{3} & Cycle III & P1 & 17 & 0 & \multirow{2}{*}{$100 \%$} \\
\cline { 3 - 4 } & & P2 & 17 & 0 & \\
\hline
\end{tabular}

From table 1.1 above, it can be seen from cycle I to cycle III an increase in teacher activity. Based on table 1.1 the teacher has not fully carried out the activities contained in the teacher observation sheet. In the preliminary activities, some activities have not been done by the teacher, namely in the first cycle of meeting 1 the teacher has not conveyed the learning objectives, motivation, and has not invited students to conclude the learning that has been learned. Then at meeting 2 in the preliminary activities the teacher has not submitted the learning objectives and has not concluded the material that has been learned. In cycle II in the preliminary activities at the meeting 1 teacher has not conveyed the learning objectives, and at the meeting, 2 teachers have not motivated students. However, in cycle II in the preliminary activities, the teacher has carried out all activities contained in the teacher activity observation sheet. 
In the Core Activities, the teacher has carried out all learning activities from cycle I to cycle III. In Cycle I to Cycle III the teacher carries out the Connecting phase where the teacher connects the material to be studied with daily life or connects the material to be learned with material that has been studied previously. Then in the Organizing stage, the teacher conveys the material to organize ideas from students. Besides the teacher also organizes students into several groups to solve a problem in the worksheet with the guidance of the teacher, the teacher guides students to solve the problems that are in the worksheet. At the Reflecting stage, the teacher allows students to make a presentation. At the Extending stage, the teacher gives a question to deepen student knowledge.

In the closing activities in the first cycle of meeting 1 and meeting II, the teacher has not carried out one of the activities contained in the teacher observation sheet that is the teacher has not invited students to conclude the learning outcomes that have been learned. But in cycle II and cycle III the teacher has carried out all the activities contained in the teacher activity observation sheet. This shows that the teacher's activity increased quite well from cycle I to cycle III. The teacher's activity in each cycle can be increased due to reflection so that the teacher can improve the deficiencies in each cycle.

2. Student activities

Observation of student activities from cycle I to cycle III has increased. The percentage of average scores for student activities can be seen in Table 1.2 below:

Table 1.2 Recapitulation of Student Activity Results

\begin{tabular}{|c|c|c|c|c|c|}
\hline \multirow[t]{2}{*}{ Number } & \multirow[t]{2}{*}{ Cycle } & \multirow[t]{2}{*}{ Meet } & \multicolumn{2}{|c|}{ Implementation } & \multirow[t]{2}{*}{ Average } \\
\hline & & & Yes & No & \\
\hline \multirow[t]{2}{*}{1} & \multirow[t]{2}{*}{ I } & $\mathrm{P} 1$ & 6 & 2 & \multirow[t]{2}{*}{$81,25 \%$} \\
\hline & & $\overline{\mathrm{P} 2}$ & 7 & 1 & \\
\hline \multirow[t]{2}{*}{2} & \multirow[t]{2}{*}{ II } & $\overline{\mathrm{P} 1}$ & 8 & 0 & \multirow[t]{2}{*}{$100 \%$} \\
\hline & & $\overline{\mathrm{P} 2}$ & 8 & 0 & \\
\hline \multirow[t]{2}{*}{3} & \multirow[t]{2}{*}{ III } & $\mathrm{P} 1$ & 8 & 0 & \multirow[t]{2}{*}{$100 \%$} \\
\hline & & $\mathrm{P} 2$ & 8 & 0 & \\
\hline
\end{tabular}

Based on observations of student activities in cycle I, cycle II, and cycle III which can be seen in Figure 1.2 above there is a good increase. This is because there is a discussion to discuss and correct deficiencies that make students less active in learning. From the table and graph above, the student activities from cycle I to cycle III have increased. This can be seen students focus more attention on the teacher, students dare to present the results of the discussion, responding to their peers. In cycle I some students do not pay attention when the teacher explains the material, they are more cool to chat with friends and sleep in class, it can be seen in Figure 1.1. 

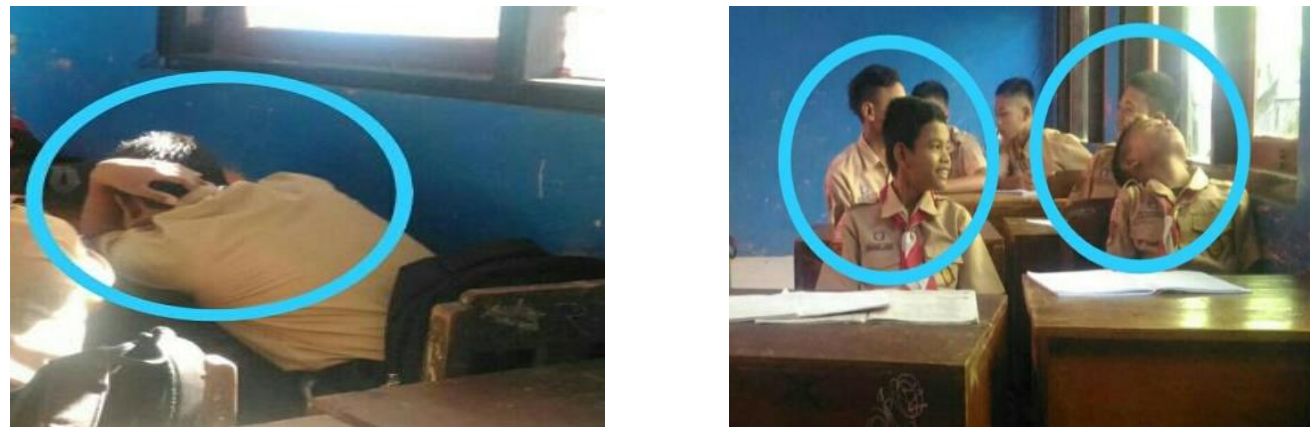

Figure 1.1 Students Do Not Pay Attention to Teacher's Explanation

Also, students still do not dare to present the results of their discussions, giving responses to other groups who have presented the results of their discussions in cycle I. In cycle II there were still chatting with their friends when the teacher explained, this can be seen in Figure 1.2. In cycle III students are very enthusiastic in learning, they are confident to present the results of the discussion. Students present the results of the discussion can be seen in Figure 1.3. This is because students have been able to adjust to the learning used by the teacher, the CORE learning model. This model also encourages an increase in students' mathematical connection abilities and self-efficacy because then students will have confidence when working on the assignments of the teacher.

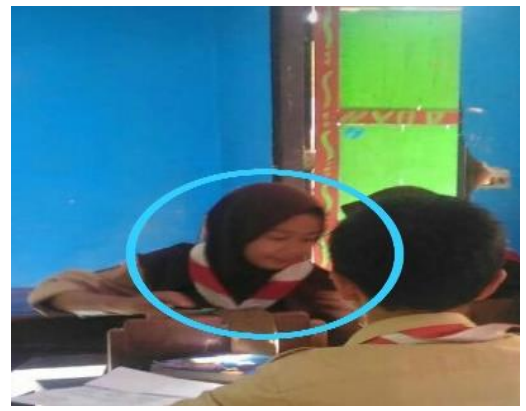

Figure 1.2 Students do not pay attention to the teacher's explanation

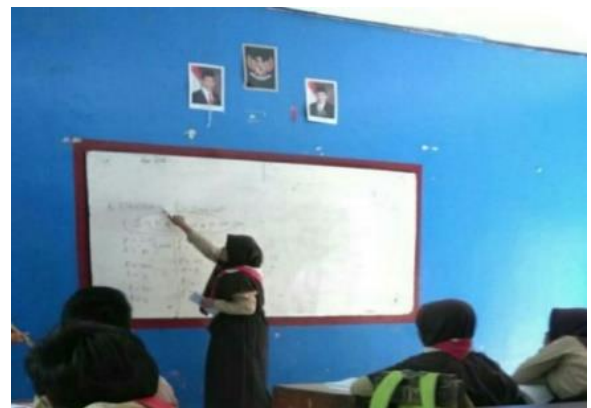

Figure 1.3 Students Presenting Discussion Results

3. Students' mathematical connection skills

The ability of students' mathematical connections from cycle I to cycle II and from cycle II to cycle III has improved. This can be seen in Table 1.3 below: 
Table 1.3 Recapitulation of Mathematics Connection Capability Test Results

\begin{tabular}{|l|l|l|l|}
\hline Indicator & Cycle I & Cycle II & Cycle III \\
\hline 1 & 24,68 & 28,85 & 29,81 \\
\hline 2 & 17,95 & 21,79 & 24,36 \\
\hline 3 & 22,12 & 26,60 & 27,24 \\
\hline Average & 64,74 & 77,24 & 81,41 \\
\hline
\end{tabular}

From table 1.3 above it can be seen that the mathematical connection ability of students increases. In the cycle, the average value of students was 64.74 . In cycle II, there was an increase compared to cycle II, with an average grade of 77.24. In cycle III also increased compared to cycle II, the average value for cycle III was 81.41. With an increase in the average value from cycle I to cycle II and from cycle II to cycle III has increased, it means that the ability of students' mathematical connections in class VII D increases.

The first indicator that is recognizing and using the relationship between sub material in a subject matter mathematics from cycle I to cycle III has increased. In cycle, I obtained an average of 24.68 , in cycle II obtained an average value of 28.85 . And at the end of cycle III obtained an average value of 29.81. This increase occurs because the indicator is supported by the Connecting stage, where the teacher connects the previous material with the material to be studied. This makes students understand how the relationship between sub material in one subject matter mathematics.

In the second indicator, understanding the relationship between concepts in mathematics from cycle I to cycle III has increased. In cycle, I gained an average of 17.95, in cycle II obtained an average value of 21.79. And at the end of cycle III obtained an average value of 24.36. This increase occurs because in the Extending stage students are accustomed to working on problems related to the previous material. So that makes students understand how the relationship between the material being studied with the previous material.

The third indicator is to recognize and apply mathematics in everyday life from cycle I to cycle III has increased. In cycle, I gained an average of 22.12, in cycle II obtained an average value of 26.60. And at the end of cycle III obtained an average value of 27.24. This increase occurs because in LKS students are accustomed to dealing with questions in the form of stories related to everyday life so that students can understand how the relationship between mathematics in everyday life.

Also, from table 1.3 above it can be seen that there are indicators that have the lowest average compared to the others, namely the second indicator. The second indicator is still low because students can connect but in the calculation process students still find it difficult. In finding $\mathrm{x}$ and $\mathrm{y}$ grades, the student forgets how to operate it. Students can not fully remember the material that has been studied previously. This can be seen from the results of students' answers in Figure 1.4. This is consistent with the results of research from Subekti, E et al (2016) that moderate-able students can connect between concepts but in their calculations still cannot be because students have completely forgotten about the previous material 


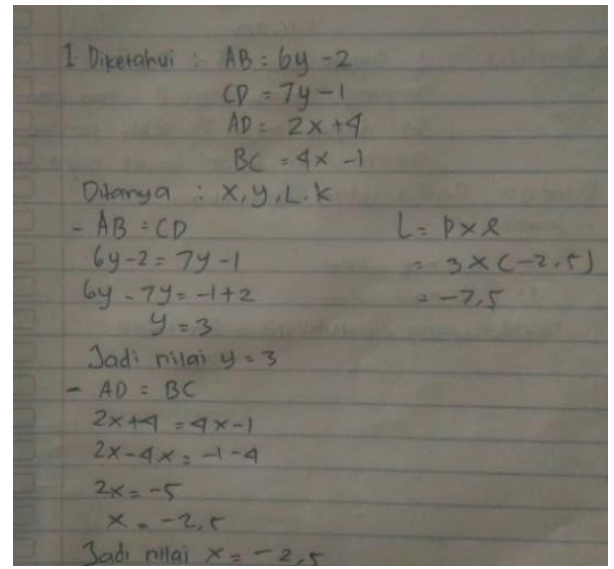

Figure 1.4 Student Answers Are Not Right

It can also be seen in table 1.3 that there are indicators that have the highest average value compared to the others, namely the indicators recognize and use the relationship between sub material in one subject matter of mathematics. The first indicator is the highest because students can understand the problem well. Students can write what is known and asked about the problem. Then students can connect between sub material, this can be seen when students look for the side of a square that has a known area, then students calculate the circumference of a square, and get the right answer at the end of the process. This is in line with the results of research from Subekti, E.S et al., Who explained that capable students can recognize and use the relationship between ideas in mathematics. The answer can be seen in Figure 1.5.

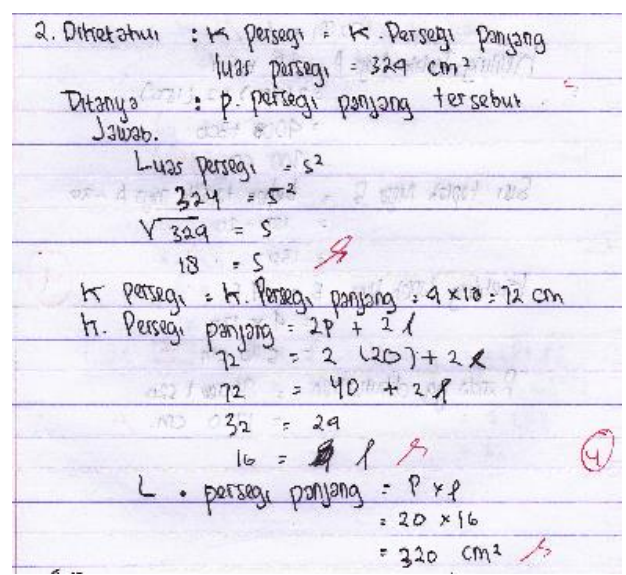

Figure 1.5 Student Answers Right

Mathematics learning is usually presented with conventional learning where the teacher still uses lecture methods that do not involve student roles. After applying the learning process in mathematics through the CORE learning model (Connecting, Organizing, Extending, and Reflecting), students become more enthusiastic to learn because there is a role for students, namely students can connect themselves between material and daily life, students make presentations which requires confidence, and students become more active in responding to the results of the discussion. Based on the description that has been described, it can be concluded that the use of CORE learning makes students truly understand the subject matter being taught. 


\section{Self-efficacy}

Increased self-efficacy or student confidence in this study increased from cycle I to cycle II and from cycle II to cycle III. This can be seen based on the results of observations through the self-efficacy questionnaire presented in table 1.4 below:

Table 1.4 Recapitulation of Average Self-Efficacy Questionnaire Classes

\begin{tabular}{llll}
\hline Indicator & Cycle I & Cycle II & Cycle \\
\hline 1 & 12,36 & 14,61 & 15,25 \\
\hline 2 & 13,42 & 14,61 & 15,15 \\
\hline 3 & 17,54 & 18,45 & 19,96 \\
\hline 4 & 14,06 & 14,45 & 15,25 \\
\hline 5 & 12,32 & 13,83 & 14,47 \\
\hline Average & 69,67 & 76,05 & 79,85 \\
\hline
\end{tabular}

From table 1.4 above shows that there is an increase in the average self-efficacy of students from cycle I to cycle II and cycle II to cycle III. In the first cycle, the average self-efficacy of students reached 69.67 , in the second cycle the average self-efficacy of students increased to 76.05, and in the third cycle, the average self-efficacy of students increased to 80.08. Also, an increase in self-efficacy can be proven by the existence of a student named M Jabbar who has a value in cycle I of 64.29 , in cycle II of 70.24 , and at the end of cycle III of 72.61 .

The first indicator that can complete tasks that are easy to difficult from cycle I to cycle III has increased. In cycle, I obtained an average of 12.36, in cycle II obtained an average value of 14.61. And at the end of cycle III obtain an average value of 15.25. This increase occurs because it is supported by the Extending stage, where students are given a problem and ask students to work on it. This can train students whether they can deal with easy or difficult problems.

The second indicator that can deal with mathematical tasks beyond the ability of cycle I to cycle III has increased. In cycle, I gained an average of 13.42, in cycle II obtained an average value of 14.61. And at the end of cycle III obtain an average value of 15.15. This increase occurs because it is supported by the Extending stage, where students are given a problem and ask students to work on it. This can train students whether students can deal with mathematical tasks beyond their abilities or not.

The third indicator that can survive and be tenacious in doing mathematical skills from cycle I to cycle III has increased. In cycle, I obtained an average of 17.54 , in cycle II obtained an average value of 18.45. And at the end of cycle III obtained an average value of 19.96. This increase occurs because at the Organizing stage the teacher will ask students to discuss it, this can see how students do it, whether students can survive and tenacious in doing math problems or not.

In the fourth indicator, the influence of personal experience from cycle I to cycle III has increased. In cycle, I gained an average of 14.06, in the second cycle obtained an average value of 14.56. And at the end of cycle III obtain an average value of 15.25. This improvement occurs because it is supported by CORE learning in the Connecting phase, where students can connect between the previous material and the material to be studied so that students can strengthen aspects of mastering his personal experience.

In the fifth indicator, the readiness to deal with situations from cycle I to cycle III has increased. In cycle, I obtained an average of 12.32, in cycle II obtained an average value of 13.83. And at the end of cycle III obtained an average value of 14.47. This improvement 
occurs because it is supported by the Reflecting stage, where when one of the groups makes a presentation, students can discuss with their friends to evaluate their work, whether the answer is correct or not. This can train students to deal with any situation that occurs.

Besides, in table 1.4 it can be seen that there are indicators that have the lowest average values, namely indicators of readiness to deal with situations. The fifth lowest indicator among the other indicators because students are not ready to face the situation, for example when during the reflecting stage, there are still students who do not want to respond to the work of friends who have made presentations, then at the connecting stage when asked about the material will be studied, they are still hesitant in answering because they did not learn before starting learning.

\section{CONCLUSION}

Based on the results of research that researchers have done for three cycles to increase the ability of mathematical connections and self-efficacy through CORE learning in class VII D of SMP Negeri 3 Sidareja it can be concluded as follows:

1. An increase in students' mathematical connection ability as indicated by an increase in the average grade of the mathematical connection test class in each cycle. Besides, the average value of each indicator in the mathematical connection test also showed an increase.

2. An increase in students' self-efficacy is indicated by an increase in the average value of the self-efficacy questionnaire class in each cycle. Also, the average value of each indicator in the self-efficacy questionnaire showed an increase.

\section{REFERENCES}

Bandura, A. Self Efficacy: The Exercise Of Control. New York: W.H. Freeman Company. 1997: 33-55

Lappan, G. dkk. Getting to Know Connected Mathematics : An Implementations Guede. Upper Saddle River, New Jersey: Prentice Hall. 2002: 1-50

Lestari, K.E dan Yudhanegara, M.R. Penelitian Pendidikan Matematika. Bandung: PT.Refika Aditama. 2015: 49-52

National Council of teacher Mathematics. Principles and Standars for School Mathematics. Reston, VA:NCTM. 2000: 29-69

Santrock J.W. Psikologi Pendidikan. Jakarta: Kencana Prenada Media Group. 2014

Sabandar, J. 'Berpikir Reflektif'. Makalah Pembicara Utama Seminar Nasional Matematika. Bandung. 2007: 1-17

Subekti, E.F dkk. (2016). Analisis Kemampuan Koneksi Matematis Siswa Kelas Vii Smp Negeri 1 Kembaran Materi Bangun Datar. Prosiding Seminar Matematika dan Pendidikan Matematika. Surakarta. 2016; 403-414

Sugiman. Koneksi Matematik dalam Pembelajaran Matematika di Sekolah Menengah Pertama. Jurnal Phytagoras. 4(1): 56-66

Sumarmo, U dan Permana, Y. Mengembangkan Kemampuan Penalaran dan Koneksi Matematis Siswa SMA Melalui Pembelajaran Berbasis Masala. Jurnal Educationist.2007; 1(2): 116-123 